\title{
Evaluation of Bacteria Isolated from Olive Mill Wastewater as Plant Growth Promoter on Basil (Ocimum basilicum L.) plant
}

\author{
Ghada A. Z. Ibrahim
}

\begin{abstract}
The aim of this study was evaluate Enterobacter asburiae as plant growth promoter, through a field experiment conducted at Baloza Research Station at Season 2017/2018 on the production of Basil (Ocimum basilicum L., Family: Lamiaceae). The results showed increasing in growth parameters and essential oil yield by Ent. asburiae treatment and Ent. asburiae + half dose of $\mathrm{N}_{2}$ treatment than the control. Ent. asburiae produced phytohormones and amino acids which increased plant growth parameters. The enhanced essential oil has antibacterial activity which showed as a zone of inhibition around bacterial growth on agar plates. Enterobacter asburiae produced ammonia which decreased fungi counts. The more positive response of the oils extracted of treated plant showed essential the presence of gram negative strains (Pseudomonas sp.) and gram positive strains (Listeria sp. and Bacillus cereus) by using Enterobacter asburiae treatment.
\end{abstract}

Keywords: Basil, Enterobacter asburiae, growth promoting bacteria, biofertilizer, essential oil as antibacterial.

\section{INTRODUCTION}

Genus Enterobacter spp. as plant growth promoting bacteria is a Gram-negative, short rod and motile with flagella are having characteristics in nitrogen fixation, plant growth and enhancement. Enterobacter sp. is highly phosphate solubilizer, soil phosphorus solubilisation, producer of indole acetic acid (IAA), exopolysaccharides which increase soil porosity, ACC deaminase, HCN antibiotics, siderophore and chitinase, (Kumer et al., 2011).

Basil (Ocimum basilicum L., Family: Lamiaceae) is a spicy herb used in fresh and dried forms as seasoning. In Mediterranean countries, the herbal medicine is used also in cosmetic industries and perfumes, and basil essential oil used as antibacterial (Toaima and Hamed, 2016).

Microorganisms have an important role in recycling of nutrients. They reduce the use of chemical fertilizers. The relationship between plant growth promoting bacteria and medicinal plants is still to be explored. There are beneficial bacteria stimulate plants to growth, (Baljeet and Shuchita, 2015).
Baljeet and Shuchita (2015) described that Enterobacteriaceae as plant growth promoting bacteria. Laura Buckler (2018) reported that the chemical fertilizers are important for the cost production of commercial crops, in the last century. However, using chemical fertilizers caused damage and accumulation on long-term. One of the problems with chemical fertilizers is contamination and pollution the soil and the groundwater and other water sources. Now, NPK in small quantities is non-toxic, but a lot can damage the balance of nature in many ways. So it's important to decrease using chemical fertilizers and supplementation biofertilizers as a safe way to keep the environment and take high plant productions. The objective of this study was to evaluate the strain of Enterobacter asburiae as a plant growth promoter on Basil parameters under field conditions.

\section{MATERIALS AND METHODS}

\section{1- Isolation of Enterobacter asburiae}

Sample of olive mill wastewater (OMWW) was collected and Enterobacter asburiae was isolated for its evaluation as a growth promoting bacteria on basil plant. Ramsay's medium (Ramsay et al., 1983) was used for isolating phenolic compounds degrading bacteria.

The 16S rRNA gene sequences as for used to study bacterial phylogeny and taxonomy. The most common, Enterobacter asburiae was identified using methods described by Bergy's Manual of Determinative Bacteriology (1994). The bacterial isolate was also identified by partial $16 \mathrm{~S}$ rRNA gene sequence analysis according to Berg et al. (2002). It was identified by partial (16S rRNA) gene sequence analysis as Enterobacter asburiae according to Karpouzas et al. (2000). El-Asli et al. (2005) suggested that the phylogenetic analysis of $16 \mathrm{~S}$ ribosomal DNA showed that all the related sequences are members of the Enterobacteriaceae family.

\section{2- Field experiment}

Field experiment was conducted at Baloza Research Station - Desert Research Center, Egypt during summer 2017/2018. The main physical and chemical properties of the soil of field experiment are shown in Table (2). Basil (Ocimum basilicum L.) was the task crop. Field experiment involved 3 plots (3 treatments in 3

DOI: 10.21608/ASEJAIQJSAE.2019.66049

${ }^{1}$ Department of Soil Fertility and Microbiology, Desert Research Center, Cairo, Egypt

Received November 13, 2019, Accepted December 22, 2019 
replicates), each plot has $6 \mathrm{~m}^{2}\left(2 \times 3 \mathrm{~m}^{2}\right)$. Inorganic fertilizers were added during soil field preparation. Six $\mathrm{m}^{3}$ of organic compost were applied through preparation of soil. The applied inorganic fertilizers were ammonium nitrate $(33.3 \% \mathrm{~N})$ at $150 \mathrm{Kg} /$ feddan (added half dose), superphosphate $\left(15.5 \% \mathrm{P}_{2} \mathrm{O}_{5}\right)$ at $200 \mathrm{Kg} / \mathrm{fed}$. and potassium sulphate $\left(48.5 \% \mathrm{~K}_{2} \mathrm{O}\right)$ at $100 \mathrm{Kg} / \mathrm{fed}$. The plant yield was collected after 5 months from cultivation for first cut and after 45 days from the first cut for the second cut. The plants were soil treated with $100 \mathrm{ml}$ of bacterial inoculum $\left(10^{8} \mathrm{CFU}\right)$.

The grains of Basil (Ocimum basilicum L.) were provided by Agriculture Research Center, Ministry of Agriculture and Land Reclamation (MALR), Cairo Egypt. Throughout this work, germination test was carried out to make sure of the viability of grains.

\section{3- Plant growth parameters}

The following plant growth parameters were measured in the field fresh weights and dry weights of total biomass were determined. Biological yield was determined after 150 and 195 days from planting and the result was expressed as per cent ratio of oil yield.

\section{4- Chemical analysis}

Total nitrogen content in shoots and grains was determined by modified Kjeldahl method (Chapman and Pratt, 1961), while phosphorus was measured according to Watanabe and Olsen (1965) and potassium was determined by flame photometer (Bremner and Mulvaney, 1982).

Essential oil chemical constituents: Volatile oils for the $1^{\text {st }}$ and $2^{\text {nd }}$ cuts were analyzed by Gas Chromatography -Mass Spectrometry instrument (GCMS analysis) at National Research Center, Egypt. TRACE GC Ultra Gas Chromatographs (THERMO Scientific Corp., USA), (Toaima and Hamed, 2016).

Phytohormones: The auxin group phytohormones

Table 1. Identification of Enterobacter asburiae

\begin{tabular}{llcc}
\hline \multirow{2}{*}{ Quality Sequence } & \multicolumn{3}{c}{ 16S rRNA gene sequencing } \\
\cline { 2 - 4 } $\begin{array}{l}\text { CTTCTTTTGCAACCCACTCCCATGGTGTGAC } \\
\text { GGGCGGTGTGTACAAGGCCCG }\end{array}$ & $\begin{array}{l}\text { Enterobacter } \\
\text { asburiae }\end{array}$ & NR_024640 & Similarity \\
\hline
\end{tabular}

\section{2-Field experiment}

Table 2. The main Physical and chemical properties of the experimental soil at Baloza station

\begin{tabular}{|c|c|c|c|c|c|c|c|c|c|c|c|c|c|c|}
\hline \multicolumn{3}{|c|}{$\begin{array}{c}\text { Particle size } \\
\text { distribution }(\%)\end{array}$} & \multirow[t]{2}{*}{ Texture } & \multirow[t]{2}{*}{$\begin{array}{c}\mathbf{E C} \\
(\mathbf{d S} / \mathbf{m})\end{array}$} & \multirow[t]{2}{*}{ pH } & \multicolumn{3}{|c|}{ Nutrients content } & \multicolumn{6}{|c|}{ Water soluble ions (mg/L) } \\
\hline : & 卷 & है & & & & $\begin{array}{l}\mathbf{P} \\
\%\end{array}$ & $\begin{array}{c}\mathrm{Na}^{+} \\
\%\end{array}$ & $\begin{array}{r}\mathbf{K}^{+} \\
\%\end{array}$ & $\underset{(\mathrm{mg} / \mathbf{l})}{\mathrm{Ca}^{++}}$ & $\begin{array}{c}\mathrm{Mg}++ \\
(\mathrm{mg} / \mathrm{l})\end{array}$ & రి & $\underset{(\mathrm{mg} / \mathrm{l})}{\mathrm{HCO}_{3}^{-}}$ & ì & $\dot{v}$ \\
\hline 92 & 6 & 5 & Sand & 1.35 & 8.30 & 0.43 & 4.78 & 0.54 & 3.65 & 4.40 & nd & 3.84 & 6.5 & 3.2 \\
\hline
\end{tabular}

(indole-3-acetic acid (IAA) and indole-3-butyric acid (IBA)) were determined by HPLC Ultimate 3000 Thermo dionex, Germany, at central laboratory of Desert Research Center.

Exopolysaccharides production was determined by sucrose medium (Amellal et al., 1998).

Total amino acid content: The acid hydrolyzed amino acids by amide bond breakage were determined according to Pellet and Young (1980).

\section{5- Microbiological analysis}

Counting of different microbial densities in samples from soil rhizosphere was conducted on different media according to the following methods: Ashby's medium (Abd- El - Malek and Ishac, 1968) was used for counting of nitrogen fixers by M.P.N technique and calculated using Cochren's Tables, (Cochran, 1950), MacConkey's medium (Windle, 1958) was used for Enterobacteriacae counting at $37{ }^{\circ} \mathrm{C}$ for $24 \mathrm{~h}$., in broth tubes counting and at $44^{\circ} \mathrm{C}$ for $24 \mathrm{~h}$., by plate count technique, and total microbial counts did by nutrient agar medium (Jacobs and Gerstein, 1960).

6-The antibacterial activity of essential oil in vitro: It was confirmed by determining basil essential oil on growing bacteria using plates incubated at $24 \mathrm{~h}$. for treatments and $48 \mathrm{~h}$ for control according to Sharma and Sihag (2013).

\section{Statistical analysis}

The obtained data were subjected to statistical analysis by ANOVA using the method described by Sndecor (1966).

\section{RESULTS AND DISCUSSION}

\section{1- Identification of Enterobacter asburiae}

Table (1) showed the close data base match and similarity of Enterobacter asburiae. 


\section{3- Plant growth parameters}

Figure 1 showed significant increase in fresh weight of second cut as a result of Ent. asburiae treatment and by using Ent. asburiae + half dose of $\mathrm{N}_{2}$ treatment. As shown in Fig 2 there is significant increased in dry weight of the first cut by using Ent. asburiae treatment to $(80 \%)$, and at the second cut by using Ent. asburiae + half dose of $\mathrm{N}_{2}$ treatment to $(48.2 \%)$, Kumer et al. (2011) found significant increasing in plant dry weight by Ent. asburiae treatment compared with uninoculated (control) Khalifa et al. (2016) inoculated Pisum sativum with $E$. cloacae which significantly improved the growth parameters (dry weight) including grain legume compared to the non-treated plants.

\section{4- Chemical analysis}

Nitrogen: Fig 3 showed that treatment by Enterobacter asburiae increased $\mathrm{N}$ content in plant of the first and second cut (0.35 and $0.92 \%$, respectively). The treatment of Ent. asburiae + half dose of $\mathrm{N}_{2}$ gave high ratio of $\mathrm{N}_{2}$ compared with control in the second cut $(0.895 \%)$. Ogbo and Okonkwo (2012) reported that the higher concentration of nitrogen in maize seedlings treated with inoculums by Enterobacter sp. compared with those grown without it inoculation.

Phosphorus: Fig 4 showed that treatment by Enterobacter asburiae increase phosphorus content of the first cut $(0.115 \%)$ and treatment by Ent. asburiae + half dose of $\mathrm{N}_{2}$ increased phosphorus content. Deepa et al., (2010) found that Enterobacter asburiae (NII-0934) was producing IAA, P-solubilizers and $\mathrm{HCN}$. They reported that stimulation of P-solubilizing activity were plant growth of cow pea (Vigna unguiculata (L.)".

Potassium: Fig 5 showed that the treatment by Enterobacter asburiae increased in potassium (2.9\%) in the first cut. The second cut Ent. asburiae + half dose of $\mathrm{N}_{2}$ treatment increased (1.7\%).

Basil essential oil: Figure 6 showed increase in the yield of oil due to using Ent. asburiae treatment at first and second cuts results which were (1.04 and 1.49\%, respectively). Ent. asburiae + half dose of $\mathrm{N}_{2}$ treatment increased the oil yield in the first cut of plant to (1.03\%). Swamy et al. (2016) reported that the essential oils have high potential in the field of biomedicine as they effectively destroy many of bacterial, fungal, and viral pathogens, due to several types of aldehydes, terpenes, phenolics and other antimicrobial compounds so that the essential oils are effective against a diverse range of pathogens.

\section{Qualitative analysis of essential oil}

Tables (3 and 4) showed wide variation in the percentage of the different essential oil compounds as a result of treatment by Ent. asburiae. Ana Cristina et al.
(2012) found that the minimal concentration of the antimicrobial agent presenting complete growth inhibition. Pinene has activity of antimicrobial against $C$. neoformans, $C$. albicans and $R$. oryzae. The significant inhibition of pinene could be related to the potent antimicrobial action of pinene against this fungus. The antimicrobial activity was even more promising against biofilm formation, which makes pinene useful in formulating strategies to limit $C$. albicans biofilm formation.

\section{Phytohormones}

Figure 7 showed that Ent. asburiae produced the auxin group phytohormones: indole-3-acetic acid (IAA) and indole-3-butyric acid (IBA), Relative heights were $88.10 \%$ and $11.90 \%$, respectively. Abraham and Silambarasan (2015) showed that E. asburiae JAS5 and E. cloacae JAS7 strains had the ability as plant growth promoting traits such as indole-3-acetic acid (IAA) production, organic acids production and solubilization of various inorganic phosphates. E. asburiae JAS5 solubilized of tricalcium phosphate, dicalcium phosphate and zinc phosphate, whereas E. cloacae JAS7 solubilized tricalcium phosphate, dicalcium phosphate and zinc phosphate".

The quantity of Exopolysaccharides (EPS) produced by Enterobacter asburiae was $(4 \mathrm{mg} / \mathrm{ml})$ this agrees with Mu'minah et al. (2015) who indicated that the improved soil structure by aggregating soil through microorganisms such as bacteria producing exopolysaccharides (EPS) which are grouped into gramnegative bacteria. The EPS are necessary for microbial life, protection of environmental stresses; like drought and salinity, and important for chemical reactions, Microbial EPS can increase the soil granules and improve plants growth by availability of nutrients, keep soil humidity and therefore enhance soil fertility, (Ohana Costa, et al. 2018).

\section{Total amino acids content}

Figure 8 showed the concentration of amino acids in Ent. asburiae broth culture. Aspartic, glutamic acid and glycine were the greatest components $(425.4,354.78$ and 401.44). Ogbo and Okonkwo (2012) found that the production of ammonia is frequently reported for PGPR, a process most probably resulting from the deamination (ammonification) of amino acids present in the peptone used for this assay. It has been suggested that ammonia may have a role in antagonism against competing flora, particularly the fungi. 


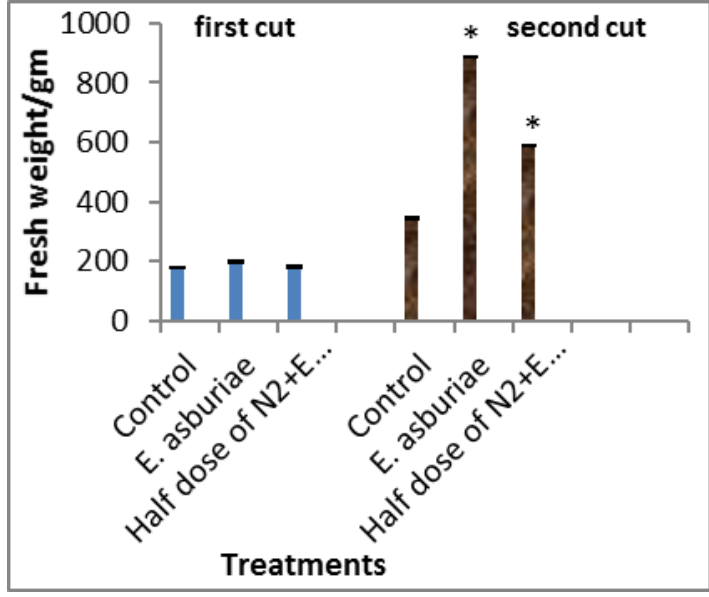

Fig. 1. Fresh weights (gm) in Basil plants

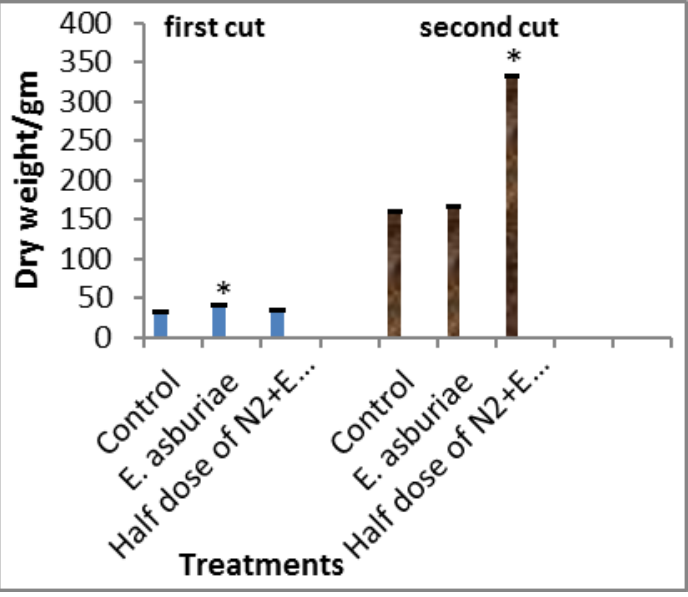

Fig. 2. Dry weights (gm) in Basil plants

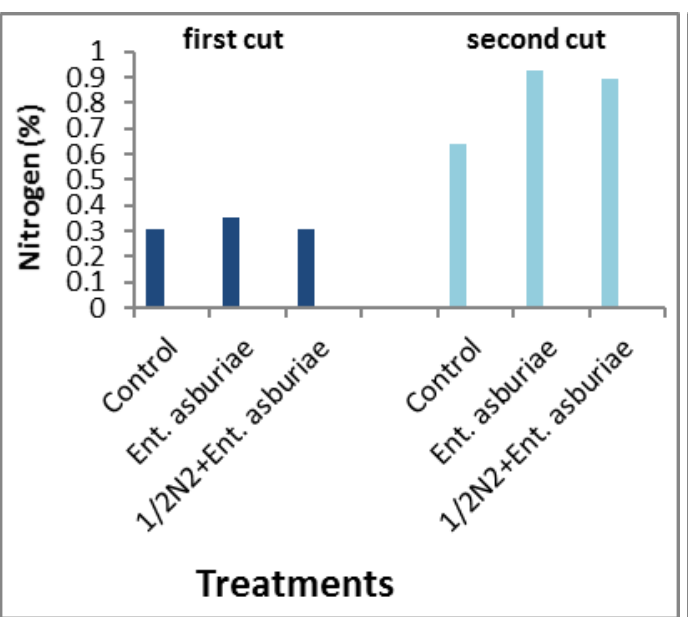

Fig. 3. Nitrogen contents in Basil plant

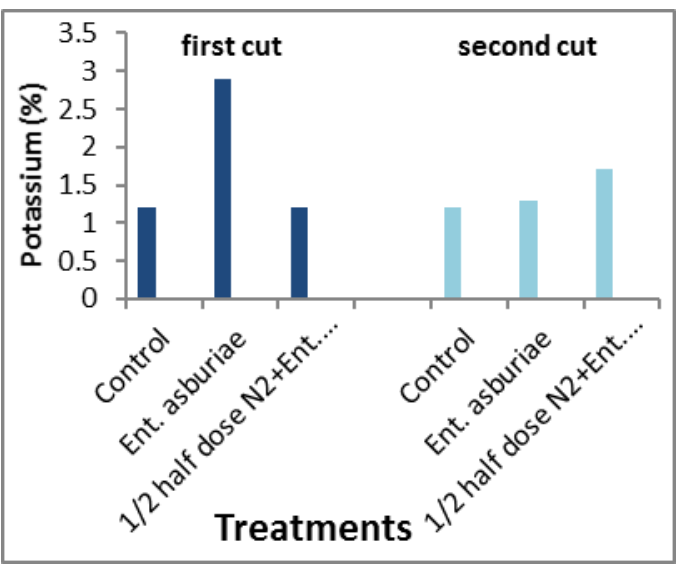

Fig. 5. Potassium contents in Basil plant

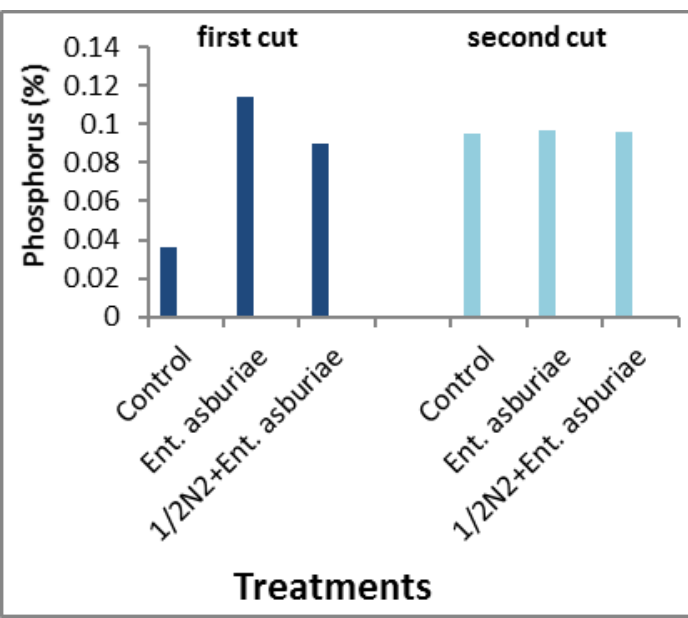

Fig. 4. Phosphorus contents in Basil plant

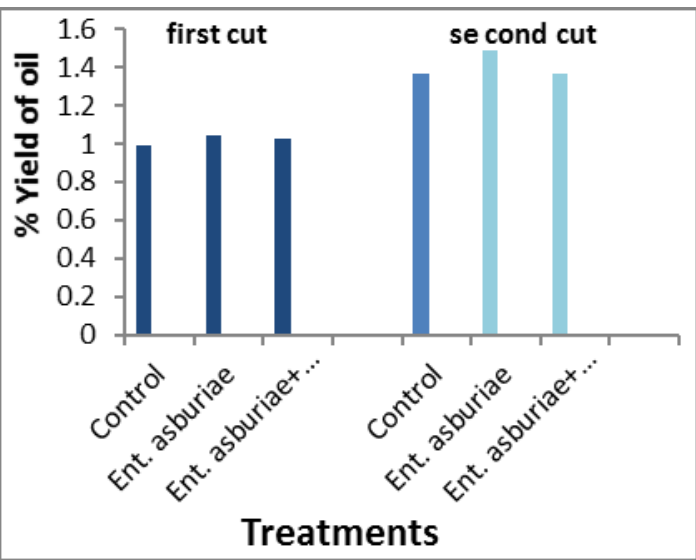

Fig. 6. Basil oil extracted essential yield 
Table 3. The analysis of essential basil oil of the control plant

\begin{tabular}{lcc}
\hline Control compounds name & Retention Time & AREA\% \\
\hline 1,8-Cineole & 7.18 & 14.39 \\
Eucalyptol & 7.18 & 14.39 \\
LINALOOL L & 9.64 & 41.40 \\
1,6-Octadien-3-ol, 3,7-dimethyl- & 9.64 & 41.40 \\
Benzene, 1-methoxy-4-(2-propenyl) (CAS) & 13.72 & 23.71 \\
Estragole & 13.72 & 23.71 \\
2-Propenoic acid, 3-phenyl-, methyl ester & 21.76 & 7.72 \\
ç-Muurolene & 31.50 & 2.16 \\
1-Naphthalenol & 31.50 & 2.16 \\
1,2,3,4,4a,7,8,8a-octahydro-1,6 dimethyl-4-(1-methylethyl) & 31.50 & 2.16 \\
à-Cadinol & 31.50 & 2.16 \\
\hline
\end{tabular}

Table 4. The analysis of essential basil oil of the treated plant

\begin{tabular}{lcc}
\hline Treatment compounds name & Retention Time & AREA\% \\
\hline 1,8-Cineole & 7.21 & 11.18 \\
Eucalyptol & 7.21 & 11.18 \\
LINALOOL L & 9.68 & 36.36 \\
1,6-Octadien-3-ol, 3,7-dimethyl- & 9.68 & 36.36 \\
Benzene, 1-methoxy-4-(2-propenyl)-(CAS) & 13.76 & 22.35 \\
Estragole & 13.76 & 22.35 \\
Methyleugenol & 22.37 & 7.72 \\
Benzene & 22.37 & 7.72 \\
1,2-dimethoxy-4-(2-propenyl)- (CAS) & 22.37 & 7.72 \\
ç-Muurolene & 31.53 & 2.42 \\
1-Naphthalenol & 31.53 & 2.42 \\
1,2,3,4,4a,7,8,8a-octahydro-1,6-dimethyl-4-(1-methylethyl) & 31.53 & 2.42 \\
à-Cadinol & 31.53 & 2.42 \\
\hline
\end{tabular}

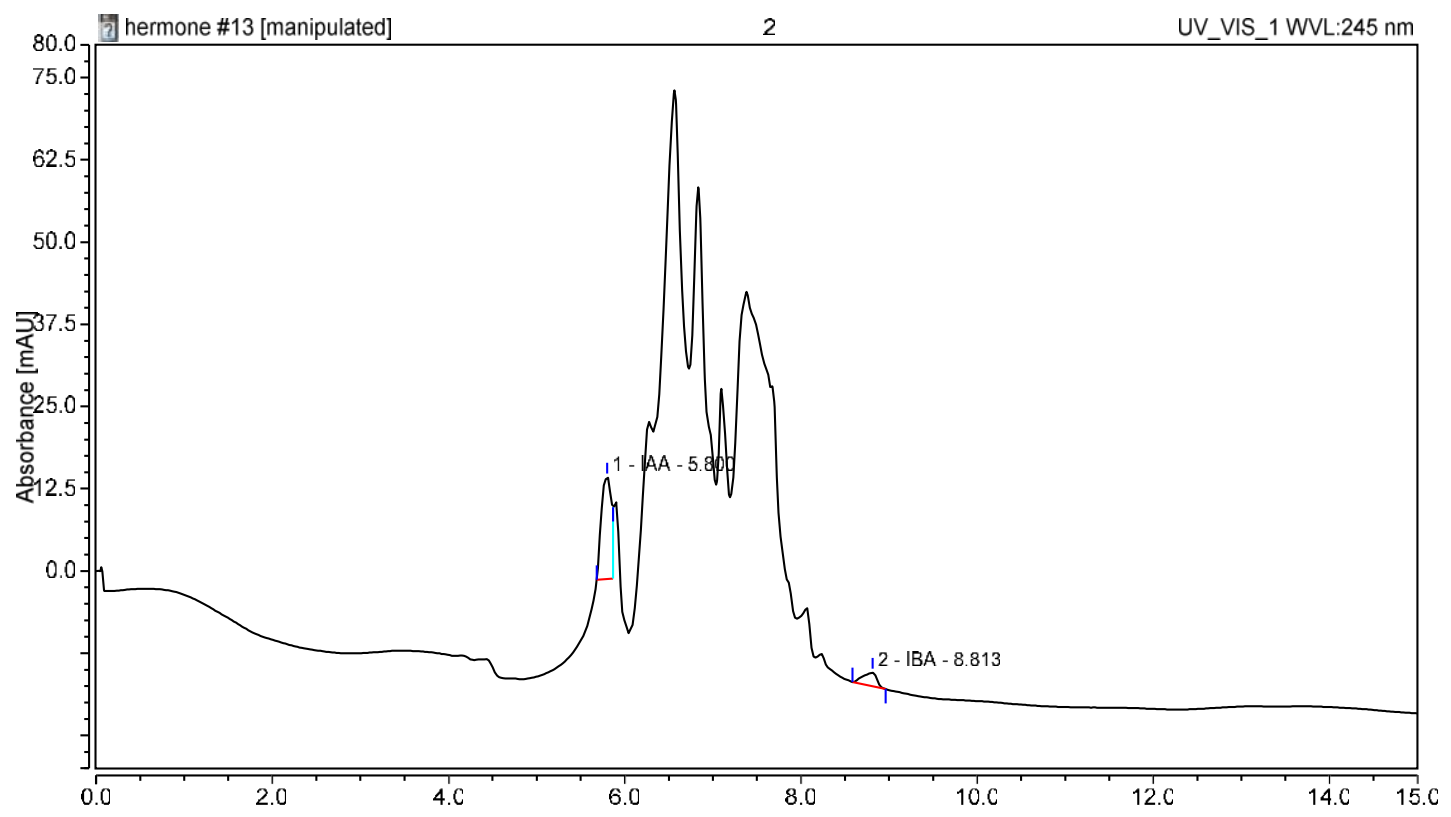

Fig 7. Phytohormones produced by Ent. Asburiae 


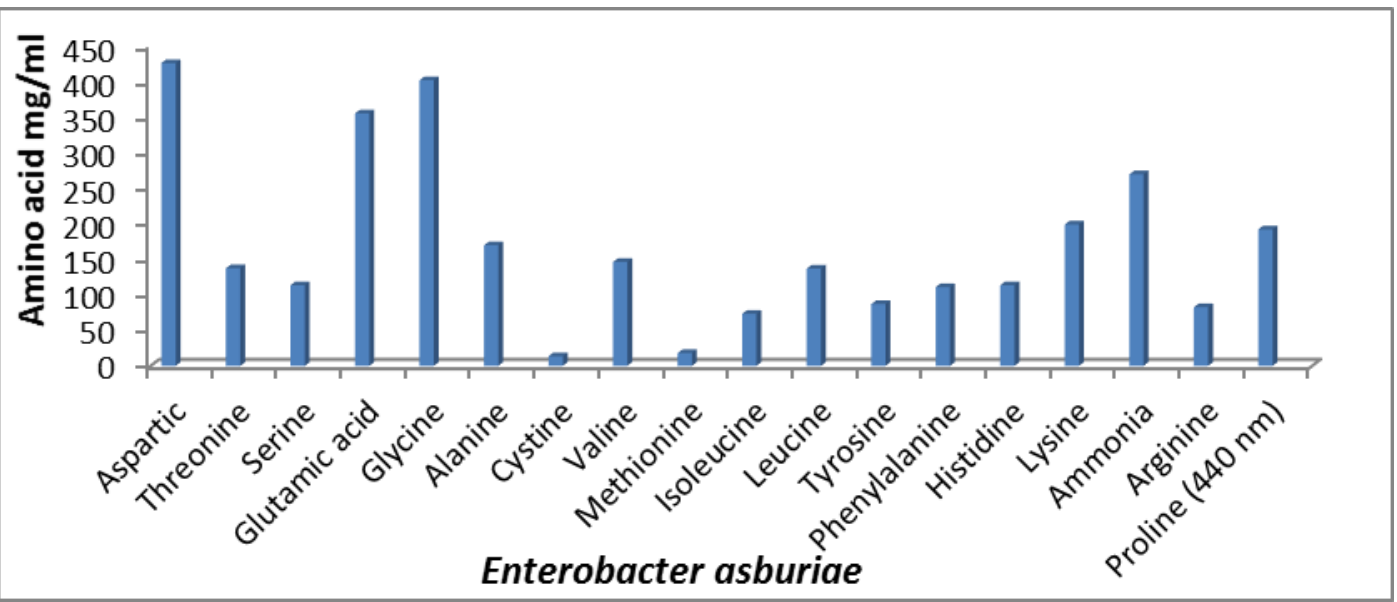

Fig 8. Amino acids determined in Ent. asburiae broth culture

These agree with Teixeira et al. (2018) who estimated that application amino acids glutamate, cysteine and glycine can act as signaling amino acids in soybean plants. Small doses are enough to increase the activity of the antioxidant enzymes, glutamate stands out for being the first amino acid in which the nitrogen absorbed by the plants a range of amino acids can be obtained through the activity of aminotransferases, In addition, amino acids such as glutamate, cysteine, and glycine may act directly or indirectly in the attenuation of plant oxidative stresses".

\section{5- Microbiological analysis}

Table 5 showed that at the first cut of rhizosphere Basil plant, there were increases in nitrogen fixers, total microbial counts and that anterobacteriacae due to inoculation with half dose $\mathrm{N}_{2}+$ Ent. asburiae treatment $\left(210 * 10^{5}, 181 * 10^{4}\right.$ and $260 * 10^{2}$, respectively). By using Ent. asburiae treatment there was high Nitrogen fixers $\left(290 * 10^{5}\right)$, total count $\left(132 * 10^{4}\right)$ and Enterobacteriacae $\left(61 * 10^{2}\right)$ more than the control. At the second cut, there were increases in nitrogen fixers, total microbial counts and Enterobacteriacae as the results of rhizosphere Basil plants by using inoculation with half dose $\mathrm{N}_{2}+$ Ent . asburiae treatment $\left(30 * 10^{6}, 158 * 10^{4}\right.$ and $183 * 10^{3}$, respectively), Estrada et al. (2004) found that although the half dose of chemical fertilizer gave a marked increase in the microorganism counts however, nitrogen addition changed microbial group's composition by reducing the prorated abundance of gram-negative bacteria in forests.

6- Antibacterial activity of essential oil in vivo: The antibacterial activity of essential oil showed inhibition zone around bacterial growth on agar plates. The more positive response oil extracted (diameter of inhibition zone) increased by treated the plant with Enterobacter asburiae. The results showed the presence of gram negative strains (Pseudomonas aeruginosa and E. coli) and gram positive strains (Listeria $s p$. and Bacillus cereus). The response of control treatment has positive effect on E. coli.

Table 5. Rhizosphere microbial counts

\begin{tabular}{llccc}
\hline Treatments & $\begin{array}{c}\text { Nitrogen fixers } \\
\text { (MPN/gm dry soil) }\end{array}$ & $\begin{array}{c}\text { Total count } \\
\text { (CFU/gm dry soil) }\end{array}$ & $\begin{array}{c}\text { Enterobacteriacae } \\
\text { (CFU/gm dry soil) }\end{array}$ \\
\hline \multirow{3}{*}{ First cut } & Control & $43 * 10^{5}$ & $117 * 10^{4}$ & $32 * 10^{2}$ \\
& Enterobacter asburiae & $290 * 10^{5}$ & $132 * 10^{4}$ & $61 * 10^{2}$ \\
& Half dose of $\mathrm{N}_{2}+$ Ent. & $210 * 10^{5}$ & $181 * 10^{4}$ & $260 * 10^{2}$ \\
\hline \multirow{3}{*}{ Second cut } & Control & $20 * 10^{6}$ & $115 * 10^{4}$ & $30 * 10^{3}$ \\
& Enterobacter asburiae & $23 * 10^{6}$ & $48 * 10^{5}$ & $36 * 10^{3}$ \\
& Half dose of $\mathrm{N}_{2}+$ Ent. & $30 * 10^{6}$ & $158 * 10^{4}$ & $183 * 10^{3}$ \\
\hline
\end{tabular}


The results showed that basil oil have a higher strength to control bacterial growth, and the essential oil is strong versus all of the estimated strains of bacteria as Escherichia coli as reported by Monika Sienkiewicz et al. (2013). Ahmad and Khan (2010) estimated Enterobacter as anti fungal agent and plant growth promoting producer. Sakkas and Chrissanthy (2017) evaluated the activity of essential basil oil's as antibacterial, because its high content of estragole and linalool Thus, The action of antimicrobial depended on some specific bacteria $P$. aeruginosa and Enterobacter spp.

\section{CONCLUSION}

Evaluation of Enterobacter asburiae isolated from Olive Mill Wastewater as Promoting Growth Bacteria under Baloza Station Research conditions on Basil (Ocimum basilicum L.) plant, gave good positive results for producing phytohormones (IAA and IBA), exopolysaccharides, amino acids, phosphate release, increased nitrogen and potassium to enhance plant growth and production. It also produced ammonia which caused antagonism against fungi. The essential oil yield by using treatments of Ent. asburiae or half dose $\mathrm{N}_{2}+$ Ent. asburiae changed the more effect on decrease the harmful microorganisms than control. This was clear in the zone of inhibition on Petri dishes. The essential oil has an antibacterial effect on Gram negative and Gram positive bacteria, but the effect on Gram negative bacteria (Pseudomonas sp.) was more than on positive samples (Listeria sp. and Bacillus cereus).

\section{REFERENCES}

Abd-El-Malek, Y. and Y.Z. Ishac. 1968. Evaluation of methods used in counting Azotobacter. J. App. Bacterio. $31: 267-275$.

Abraham, J. and S. Silambarasan. 2015. Plant growth promoting bacteria Enterobacter asburiae JAS5 and Enterobacter cloacae JAS7 in mineralization of endosulfan. Appl Biochem Biotechnol. 175:3336-48.

Ahmad, M., M.S. Khan. 2010. Plant growth promoting activities of phosphate solubilizing 618 Enterobacter asburiae as influenced by Fungicides. Eur Asia J Biosci. 4:88-95.

Amellal, N., G. Burtin, F. Bartoli and T. Heulin. 1998. Colonization of wheat roots by an EPS-producing Pantoea aggregation strain and its effect on rhizosphere soil aggregation. Appl. Environ. Microbiol. 64:37403747.

Ana Cristina, A. S., M. L. Paula, M. B. A. Mariana, C. M. C. Danielle, S. A. Celuta and S.A. Daniela. 2012. Molecules. 17:6305-6316.
Baljeet, S. S. and V. Shuchita. 2015. Evaluation of Rhizospheric Bacteria from Ocimum sp. as Potential Pgpr. Microbial Biochemical Technol.7: 088-095.

Bergy's Manual of Determinative Bacteriology. 1994. John G. Hol, Noel R. Kriey, Peter H.A. Sneath, Jamest-Staley T. Williams (ed) (Nint 1 edition) Williams and Wilkins, Baltimore London.

Berg, G., N. Roskot, A.Steidle, L.Eberl, A. Zock and K. Smalla. 2002. Plant-dependent genotypic and phenotypic diversity of antagonistic rhizobacteria isolated from different Verticillium host plants. App. Enviro. Microbio. 68: 3328-3338.

Bremner, J.M. and C.S. Mulvaney. 1982. Nitrogen. In: Page, A.L., Miller, R.H. and Keeney, D.R. (Eds.), Methods of soil analysis. Part 2, Chemical and microbiological properties. Agronomy 9, Soc. Agronomy, Madison, Wisconsin. 595-624.

Chapman, H. D. and P. F. Pratt. 1961. Methods of Analysis Soils, Plant and Waters. Univ. of California, Division Agric. Sci. Riverside, California. USA.

Cochran, W. G. 1950. Estimation of bacterial densities by mean of the (Most Probable Number) Biometrics. 6:105115.

Deepa, C.K., S.G. Dastager and A. Pandey. 2010. Isolation and characterization of plant growth promoting bacteria from non-rhizospheric soil and their effect on cowpea (Vigna unguiculata (L.) Walp.) seedling growth.

Estrada, I.B., A. Aller, F Aller, X . Gómez and A. Morán. 2004. The survival of Escherichia coli, faecal coliforms and Enterobacteriaceae in general in soil treated with sludge from wastewater treatment plants. Bioresour Technol. 93:191-8.

El-Asli, A., F. Errachidi, R.Bennisse, A. Qatibi and M.Errami. 2005. Effect of cell immobilization on the treatment of olive mill wastewater by a total phenols, acetic acid and formic acid degrading bacterium strain. Grasasy Aceites (Sevilla). 56: 116-120.

Jacobs, M.B. and M.J. Gerstein. 1960. Hand Book of Microbiology. De. Van Nostranal Co. Inc., New York. $139-202$.

Karpouzas, D. G., J. A. W. Morgan and A.Walker. 2000. Isolation and characterisation of ethoprophos-degrading bacteria. FEMS Microbio. Ecology. 33: 209-218.

Khalifa, A.Y.Z., A.Alsyeeh, M. A.Almalki, A.F.Saleh. 2016. Characterization of the plant growth promoting bacterium, Enterobacter cloacae MSR1, isolated from roots of non-nodulating Medicago sativa. 23:79-86.

Kumar Jha, Ch., A. Aeron, P. V. Patel, D. K. Maheshwari and S. Meenu. 2011. Enterobacter: Role in Plant Growth Promotion. In: Bacteria in Agrobiology: Plant Growth Responses. Chapter 81 Enterobacter: Role in Plant Growth Promotion.

Laura, B. 2018. The Hidden Dangers of Chemical Fertilizers. This article originally appeared in the April 2018 issue of Occupational Health and Safety. 
Monika, S., Ł. Monika, P. Marta, B. Wojciech and E. Kowalczyk. 2013. The Potential of Use Basil and Rosemary Essential Oilsas Effective Antibacterial Agents. Molecules. 18:9334-9351.

Mu'minaha, Baharuddinb, H.Subairc and Fahruddind. 2015. Isolation and Screening Bacterial Exopolysaccharide (EPS) from Potato Rhizosphere in Highland and The Potential as a Producer Indole Acetic Acid (IAA). Procedia Food Sci.3: $74-81$.

Ogbo, F. and J. Okonkwo. 2012. Some Characteristics of a Plant Growth Promoting Enterobacter sp. Isolated from the Roots of Maize. Advan Microbiol. 2: 368-374.

Ohana, Y. A. C., M. R. Jos and E. K. Eiko. 2018. Microbial Extracellular Polymeric Substances: Ecological Function and Impact on Soil Aggregation. Front Microbiol. 9: 1636.

Pellet, P. L. and V. R. Young. 1980. "Nutritional Evaluation of Protein Foods". Published by The UN Nation Univ. Tokyo, Japan. Nutr. Bull. Suppl. P4.

Ramsay, B.A., D.G. Cooper, A. Margaritis and J.E. Zajic. 1983. Rhodochorous Bacteria: Biosurfactant Production and Demulsifying Microbial Enhanced Oil Recovery. Penn Well Books. 61 - 65. Tulsa, Oklahoma. USA.

Sakkas, H. and C.H. Papadopoulou. 2017. Antimicrobial Activity of Basil, Oregano, and Thyme Essential Oils. J. Microbiol. Biotechnol. 27: 429-438.
Sndecor, G.W. 1966. Statistical Methods. The state Univ. Press. Ames. Lowa, U.S.A.PP.534

Sharma, P. and R.C. Sihag. 2013. Pathogenicity Test of Bacterial and Fungal Fish Pathogens in Cirrihinus mrigala Infected with EUS Disease. Pakistan J.Biological Sci. 16:1204-7.

Swamy, M.K., M.S. Akhtar and U.R. Sinniah. 2016. Antimicrobial Properties of Plant Essential Oils against Human Pathogens and Their Mode of Action: An Updated Review. Evidence-Based Complementary and Alternative Medicine. V. 21 pages.

Teixeira, W. F. , L. H. Soares, E. B. Fagan and J. N. Soares. 2018. Seed and Foliar Application of Amino Acids Improve Variables of Nitrogen Metabolism and Productivity in Soybean Crop. Research Gate. V. 9:396.

Toaima, W.I.M. and E.S. Hamed. 2016. Productivity Evaluation for some imported Basil Varieties under Siwa Oasis Conditions. Middle East J. Agric. Res. Vol. 5:810819.

Watanabe, F. S. and. S. R. Olsen. 1965. Test of an ascorbic acid method for determining phosphorus in water and $\mathrm{NaHCO}_{3}$ extracts from soil. Soil Sci. Soc. Amer. Pro. 29:677-678.

Windle, T.E. 1958. The Examination of Waters And Water Supplies 7 thed., Church; Ltc . London. 394 - 398 and 778. 


\section{الملخص العربي \\ تقييم البكتيريا المعزولة من مخلف ماء عصر الزيتون كبكتيريا معززه للنمو على نبات الريحان \\ غادة أمين زكي إبر اهيم}

انتاجيته. كما تتتج البكتيريا احماض امينية، وسكريات خارجية عديدة لها دور فى تحسين مسامية التربة. وكذللك تيسر بكتيريا الإنتيروباكتز للفوسفات. كما كانت هناك زيادة فى النيتزوجين و البوتاسيوم مما حسن نمو وانتاجية النبات وساهم فى زيادة محصول الزيت. كما وقد زاد ايضا النشاط الميكروبي بمنطقة الجذور. بالإضافة لإنتاج الإنتيروباكتر للأمونيا والتى بدورها تقاوم الفطريات. أدت معاملة الريحان ببكتيريا الإنتيروباكتر إلى زيادة

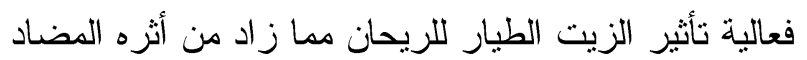

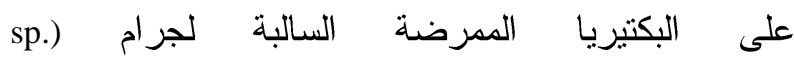

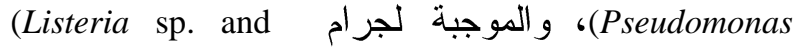
(Bacillus cereus) ويظهر ذلك فى حجم قطر هالة التثبيط حول الميكروب الممرض فى اطباق بتري.
تهدف هذه الدراسة الى تقييم السلالة البكتيرية و المعزولة من إحدى عينات (Enterobacter asburiae) مخلف ماء عصر الزيتون(المجمعة من معصرة الزيتون بمركز البحوث الزراعية) كبكتيريا معززه لنمو النبات. وقد ماءد تم اختبار ها على نمو و إنتاجية نبات الريحان. تمت التجربة الحقلية فى محطة بحوث بالوظه - مركز

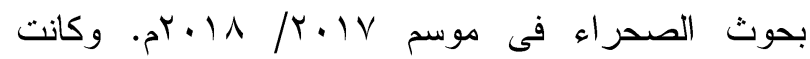
المعاملات كالآتى: معاملة كونتزول تزوى بالماء فقط،

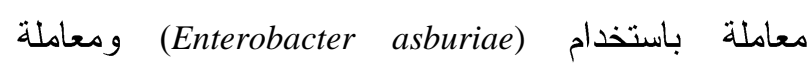
باستخدام Enterobacter asburiae + نصف جرعة التسميد الأزوتى الموصى به). وقد اظهرت النتائج أن بكتيريا الإنتيروباكتر اسبوري لها القدرة على انتاج هرمونات نباتية "أو اكسينات" (اندول اسيتيك اسيد واندول بيوتيريك اسيد) والتى تسهر فى استطالة النبات وتحسين نموه وزيادة 